\title{
The Effectiveness of Steeping Rosella (Hibiscus Sabdariffa) Against Hypertension in the Elderly
}

\author{
Tetty Rina Aritonang ${ }^{1}$, Rupdi Lumban Siantar ${ }^{2}$, Farida Mentalina Simanjuntak ${ }^{3}$ \\ 1,2,3 Stikes Medistra Indonesia, Bekasi, Indonesia \\ Email: tetty.rina.2109@gmail.com
}

\begin{abstract}
In Indonesia, hypertension is the third leading cause of death, following only stroke and tuberculosis. It is a degenerative condition in the elderly, and with growing age, nearly all feel a rise in blood pressure. Taking an infusion of rosella flowers (Hibiscus sabdariffa Linn) in the morning and evening will reduce blood pressure. Contain phytochemicals that can help lower blood pressure. This study aims to see how successfully giving rosella flower infusion (hibiscus sabdariffa linn) against hypertension in the elderly at the Matraman District Health Center. The experimental one-group pre-and post-test configuration with control was used in the analysis. The sample size was 05 people and used comparative analysis with paired t-test using computerized statistical software. The results showed that steeping Rosella does not have a significant effect on hypertension.
\end{abstract}

Keywords: Rosella Flower, Hypertension, Elderly.

\section{A. INTRODUCTION}

Hypertension is still a big issue in the world today. According to the Joint National Committee on Prevention, Detection, Evaluation, and Treatment of High Blood Pressure VII (JNC-VII), hypertension affects almost 1 billion people worldwide. According to a World Health Organisation (WHO) survey, hypertension is the leading cause of death worldwide (MOH, 2013; Aris, 2013). Hypertension is a medical term for high blood pressure. This condition can lead to various life-threatening health complications while increasing the risk of heart disease, stroke, and even death (Staessen et al., 2003).

Blood pressure can be interpreted as the force exerted by blood circulation on the body's artery walls, namely the main blood vessels in the body. The amount of this pressure depends on the blood vessels' resistance and how hard the heart is working. The more blood pumped by the heart and the narrower the arteries, the higher the blood pressure (Kowalski, 2010).

Hypertension can be detected by regularly checking blood pressure. At least, adults are advised to have blood tests, including blood pressure, every five years. Make a note of the blood pressure outcome in two figures. The first figure, or systolic pressure, reflects blood vessel pressure as the heart contracts or beats (Rahajeng \& Tuminah, 2009). Meanwhile, the second figure, or diastolic pressure, describes blood vessels' pressure while the heart is at rest between beats. A person can be said to have hypertension if the systolic blood pressure reading on the measurement for two 
consecutive days shows a result greater than $140 \mathrm{mmHg}$, and/or diastolic blood pressure readings show results more significant than $90 \mathrm{mmHg}$ (Marliani, 2013). The body's hypertension process is regulated by baroreceptors, body fluid volume regulation, the renin-angiotensin system, and autoregulation. Hypertensive people induce the activation of the hormones renin and angiotensinogen. Angiotensinogen is a blood protein inert and is formed in the liver (Kuswardhani, 2006).

The assumption that is still widely circulating in the community is that high blood pressure only needs to be lowered when disturbing, such as tension necks and dizziness. This lousy assumption needs to be straightened out. High blood pressure's adverse effects do not come immediately but only appear after a decade (Dalimartha et al., 2008). Hypertension can interfere with various organs' function, such as the kidneys, brain, eyes, and even the heart. High blood pressure that is left unchecked and continues to increase will cause various complications such as myocardial infarction, kidney failure, encephalopathy, and damage to the eye's cornea (Marliani, 2013).

Some people with hypertension must take medication for life to regulate blood pressure. However, if your blood pressure is controlled through lifestyle changes, you can stop taking the drug or taking it down. Always pay attention to the dose of drugs are given and side effects that may occur. In addition to the consumption of drugs, hypertension treatment can also be done through relaxation therapy, such as meditation therapy or yoga therapy. However, hypertension treatment will not run smoothly if it is not accompanied by lifestyle changes, such as living a healthy diet and living and regular exercise (Suoth et al., 2014).

Treatment of natural products that are affordable and have minor side effects is one effective way to solve health issues, and it can entice people to use natural medicines. Many medicinal plants or herbs have the potential to be used as antihypertensive drugs. The general mechanism of medicinal plants in controlling blood pressure, among others, has a dilating effect on blood vessels and inhibits angiotensin-converting enzyme (ACE). The renin-angiotensin system's inhibition may reduce the kidneys' ability to increase blood pressure (Pinasthika et al., 2011).

A breakthrough in non-pharmacological treatment to control high blood pressure with medicinal plants is rosella flowers. Rosella (Hibiscus sabdariffa) is one of the herbs helpful in preventing cancer, blood pressure, and smooth bowel movements. Roselle has been used widely in many countries as a beverage and a source of medicine. Several herbal remedies use this plant extract for diuretics, indigestion, antioxidant agents, and hypercholesterolemia. The part of this rosella flower that is used and sound is the rosella flower petals. (Saparinto \& Susiana, 2016). Rosella flowers are rich in phytochemicals that are effective for lowering blood pressure. Anthocyanins are watersoluble plant pigments. Anthocyanins are only found in plants with light colors in each part, starting from flowers, leaves, and fruit. Anthocyanins are a type of flavonoid compound (Kusumastuti, 2014). 
In terms of pharmacological handling, the community's costs are considered expensive, besides pharmacological handling also has side effects. Nonpharmacological treatment is in great demand by the community because it is straightforward to practice and does not cost too much. Besides, non-pharmacological handling does not have dangerous side effects, unlike pharmacological handling, so people prefer non-pharmacological rather than pharmacological. This is the basis of research interest in determining the effectiveness of giving rosella flowers to hypertension in the elderly.

\section{B. LITERATURE REVIEW}

\section{Rosella Flower}

Rosella flower is one of the herbal plants helpful in preventing cancer, blood pressure, and smooth bowel movements (Gilang, 2020). Rosella flowers have been used widely in many countries as a beverage and a source of medicine. Several herbal remedies use this plant extract for diuretics, indigestion, antioxidant agents, and hypercholesterolemia. Rosella is a fruit petal. It looks like a flower when dried; people call it rosella flowers (Usman \& Winarti, 2016).

Rosella flowers can be used as an ingredient for brewing, such as tea. Now it can be processed in the form of syrup, jam, and other drinks. Rosella infusion is made from dried roselle petals, red, and tastes like berries. Rosella infusion contains antioxidants, such as flavonoids which are suitable for the heart and body. To make the brew, 2 grams of dried roselle petals are used, brewed with hot water (Kusumastuti, 2014).

Roselle flowers (Hibiscus Sabdariffa Linn) have diuretic and choleretic properties, which help improve blood circulation, reduce blood viscosity, avoid high blood pressure, improve intestinal function, anti-bacterial infection, delay the growth of fungi/bacteria/parasites, muscle cramps, prevent kidney stone development, and increase stamina (Kusumastuti, 2014).

Rosella flowers contain $13 \%$ citric acid and malic acid anthocyanins, namely gossypetine and $2 \%$ hibiscin, Vitamin C, and 0.004\% - 0.005\% Protein: Fresh weight 6.7\% 7.9\% Flavonol glucoside hibiscritin - Flavonol gossypetine - (Maryani, 2008). The antioxidant content of roselle petals consists of gossipetin, anthocyanin, and glucoside hibiscin compounds. Anthocyanin is water-soluble plant pigments. Anthocyanin is only found in plants with bright colors in each part, starting from flowers, leaves, and edible fruits or vegetables (Hartati et al., 2009).

Flavonoids are effective in hypertension because they block ACE, preventing angiotensin from being converted to angiotensin II, which improves sympathetic nervous system activity, vasoconstriction of vascular smooth muscle, and increase water and sodium retention. Anthocyanin plays the most crucial function in rosella flowers (Hibiscus Sabdariffa Linn) (Juniarka et al., 2011). 
The part of the rosella flower that can be processed into food is the petals with a very sour taste (Saparinto \& Susiana, 2016). The taste of this drink is like tamarind. If you have stomach ulcers, you should be careful to add water and drink it after eating. If you add sugar, it's okay, but it's better to mix it with honey as a sweetener (Yuariski \& Suherman, 2012).

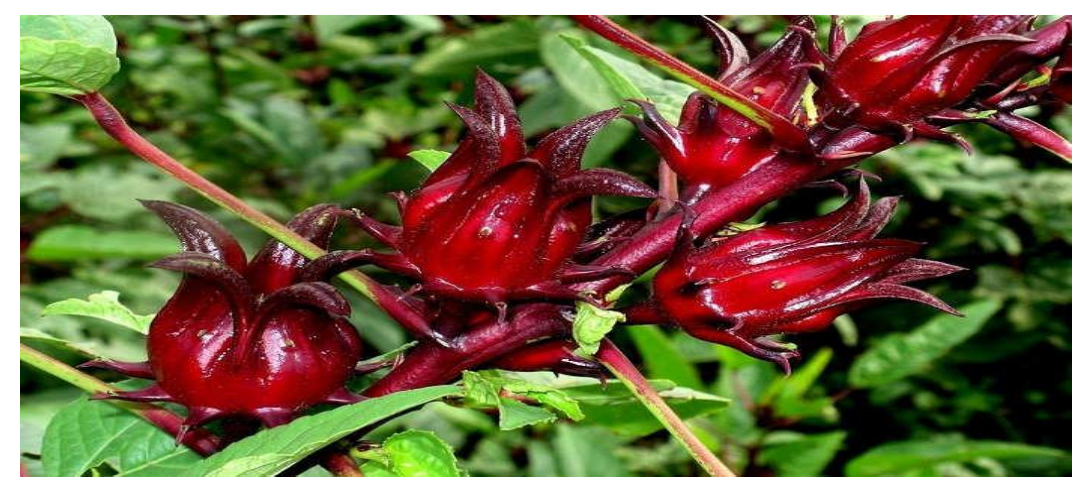

Figure 1 Rosella flower

\section{Research Hypothesis Formulation}

$\mathrm{HO}=$ There is no significant difference between pre systole and post systole BP after infusion of rosella.

$\mathrm{H} 1$ = There is a significant difference between pre systole and post-systolic BP after infusion of rosella

$\mathrm{HO}=$ There is no significant difference between BP pre diastole and BP post diastole after infusion of rosella.

$\mathrm{H} 2$ = There is a significant difference between BP pre diastole and BP post diastole after infusion of rosella.

\section{METHOD}

This research is experimental, a type of experimental research on natural ingredients to determine the roselle effect on hypertension (Jaedun, 2011). The sample size is 05 people. Using comparative analysis with paired t-test using computerized statistical software. This research was conducted at the Matraman District Health Center. The time required for the study's implementation is 1 year, effective from January to December 2020. Data analysis uses comparative analysis with the Paired TTest, using computerized statistical software. The data will be analyzed at a level of significance of $95 \%$.

\section{RESULT AND DISCUSSION}

The characteristics of the respondents in this study were the age category of seniors, amounting to 5 people with 3 respondents $(60 \%)$ female and 2 male $(40 \%)$. 
According to RISKESDAS (2013), female gender has a higher prevalence rate than men, because when women enter menopause the hormone estrogen will decrease and the risk of hypertension will increase $(\mathrm{MOH}, 2013)$.

According to Tambayong (2000) explains that the incidence of men experiencing hypertension is higher than women, but in middle age and later age, the incidence in women begins to increase, so that at the age of 65 years, the incidence in women is higher, this is due to function. estrogen hormone in middle age women begins to decline, where this hormone plays a role in increasing HDL (High Density Lipoprotein) levels, which is a supporting factor for atherosclerosis.

Table 1 With The Treatment of Steeping Rosella (Intervention)
\begin{tabular}{|c|c|c|c|c|c|}
\hline \multirow{2}{*}{ No } & Name & \multicolumn{2}{|c|}{ BP Pre } & \multicolumn{2}{c|}{ BP Post } \\
\cline { 3 - 6 } & & Systole & Diastole & Systole & Diastole \\
\hline 1 & Mrs M & 151 & 81 & 129 & 80 \\
\hline 2 & Mrs ST & 142 & 79 & 136 & 82 \\
\hline 3 & Mr TK & 168 & 95 & 137 & 87 \\
\hline 4 & Mr SS & 133 & 84 & 137 & 87 \\
\hline 5 & Mrs PS & 142 & 91 & 143 & 84 \\
\hline \multicolumn{7}{|c|}{ Mean } & $\mathbf{1 4 7 , 2}$ & $\mathbf{8 6}$ & $\mathbf{1 3 6 , 4}$ & $\mathbf{8 4}$ \\
\hline
\end{tabular}

The data will be tested using comparative analysis with paired t-test using SPSS statistical software, including pre-test and post-test blood pressure, namely for systole and diastole as shown in the table below:

Table 2 Statistical test of Systole BP Paired Samples Statistics

\begin{tabular}{|rl|r|r|r|r|}
\hline & & Mean & N & \multicolumn{1}{c|}{ Std. Deviation } & \multicolumn{1}{c|}{ Std. Error Mean } \\
\hline \multirow{2}{*}{ Pair 1 } & BP_Pre_Systole & 147.2000 & 5 & 13.25519 & 5.92790 \\
& BP_Post_Systole & 136.4000 & 5 & 4.97996 & 2.22711 \\
\hline
\end{tabular}

In table 2 above, it can be seen the results of descriptive statistics from the two samples studied, namely the pre systole and post-systole values. For the pre-systole, the mean value was 147.2000, while for the post-systole, the mean value was 136.4000. The std. deviation value for pre systole is 13.25529 and for post systole is 4.97996. Finally, for std. error, the mean pre systole value is 5.92790 and post systole is 2.22711 .

Because the average value of systolic pressure measurement between before and after the treatment of celery was obtained BP Pre systole 147.2000 > 136.4000 BP Post systole, it can be seen descriptively that there is a difference in the average result of systolic BP after infusion of rosella flowers. 
Table 3 Systole BP Significance Test Paired Samples Test

\begin{tabular}{|c|c|c|c|c|c|c|c|c|}
\hline & \multicolumn{5}{|c|}{ Paired Differences } & \multirow[t]{3}{*}{$\mathrm{t}$} & \multirow[t]{3}{*}{$\mathrm{df}$} & \multirow{3}{*}{$\begin{array}{l}\text { Sig. }(2- \\
\text { tailed) }\end{array}$} \\
\hline & \multirow[t]{2}{*}{ Mean } & \multirow[t]{2}{*}{$\begin{array}{c}\text { Std. } \\
\text { Deviation }\end{array}$} & \multirow[t]{2}{*}{$\begin{array}{l}\text { Std. Error } \\
\text { Mean }\end{array}$} & \multicolumn{2}{|c|}{$\begin{array}{l}95 \% \text { Confidence Interval } \\
\text { of the Difference }\end{array}$} & & & \\
\hline & & & & Lower & Upper & & & \\
\hline $\begin{array}{ll}\text { Pair } & \text { TD_Pre_Sistole - } \\
1 & \text { TD_Post_Sistole }\end{array}$ & 10.80000 & 15.12283 & 6.76314 & -7.97747 & 29.57747 & 1.597 & 4 & .186 \\
\hline
\end{tabular}

Based on Table 3 above, it is found that the Sig (2-tailed) value is 0.186 . Based on the significance value (Sig.), the results of the SPSS output are if Sig. (2 tailed) $<0.05$ then $\mathrm{H} 0$ is rejected and H1 is accepted and vice versa. Because the Sig (2-tailed) value is $0.186>0.05, \mathrm{H} 0$ is accepted and $\mathrm{H} 1$ is rejected.

Table 4 Diastole BP Statistical Test

Paired Samples Statistics

\begin{tabular}{|rr|r|r|r|r|}
\hline & \multicolumn{1}{|c|}{ Mean } & N & \multicolumn{1}{c|}{ Std. Deviation } & \multicolumn{1}{c|}{ Std. Error Mean } \\
\hline \multirow{2}{*}{ Pair 1 } & VAR00001 & 86.0000 & 5 & 6.78233 & 3.03315 \\
& VAR00002 & 84.0000 & 5 & 3.08221 & 1.37840 \\
\hline
\end{tabular}

In table 4 above, we can see the descriptive statistics of the two samples studied, namely the pre-diastole and post-diastole values. For pre-diastole, the average or mean value was 86.0000 , while for the post-diastole score, the average or mean value was 84.0000. The std. deviation value for pre diastole is 6.78233 and for post diastole is 3.08221. Finally, for the std. error the mean pre diastole value is 3.03315 and the post diastole value is 1.37840 .

Because the average value of the pressure measurement in the systolic area between before and after the treatment of celery, the Pre diastole TD was 86,0000 > BP 84.00000 Post diastole, it can be seen descriptively that there is a difference in the average diastolic $\mathrm{BP}$ results after steeping rosella.

\section{Table 5 Significance Test of Diastole BP}

Paired Samples Test

\begin{tabular}{|c|c|c|c|c|c|c|c|c|}
\hline & \multicolumn{5}{|c|}{ Paired Differences } & \multirow[t]{3}{*}{$\mathrm{t}$} & \multirow[t]{3}{*}{$d f$} & \multirow{3}{*}{$\begin{array}{l}\text { Sig. (2- } \\
\text { tailed) }\end{array}$} \\
\hline & \multirow[t]{2}{*}{ Mean } & \multirow[t]{2}{*}{$\begin{array}{c}\text { Std. } \\
\text { Deviation }\end{array}$} & \multirow[t]{2}{*}{$\begin{array}{l}\text { Std. Error } \\
\text { Mean }\end{array}$} & \multicolumn{2}{|c|}{$\begin{array}{l}95 \% \text { Confidence Interval } \\
\text { of the Difference }\end{array}$} & & & \\
\hline & & & & Lower & Upper & & & \\
\hline $\begin{array}{ll}\text { Pair } & \text { TD_Pre_diastole - } \\
1 & \text { TD_Post_diastole }\end{array}$ & 2.00000 & 5.29150 & 2.36643 & -4.57027 & 8.57027 & .845 & 4 & .446 \\
\hline
\end{tabular}

Based on table 5 above, the Sig (2-tailed) value is 0.446 , which means what is described in table 3 , the sig (2-tailed) value of $0.446>0.05$, so $\mathrm{H} 0$ is accepted and $\mathrm{H} 2$ is rejected. The results showed that the mean mean value for pre-systolic BP was 147.2000 $\mathrm{mm} \mathrm{Hg}$ and post-systolic BP was $136.4000 \mathrm{mmHg}$, which means that there was an average decrease in systolic $\mathrm{BP}$ of $10.8 \mathrm{~mm} \mathrm{Hg}$ after being given roselle decoction for the elderly. Whereas for TD Pre_diastole, it was obtained a value of 86,0000 and TD 
Post_diastole, it was obtained a value of 84,0000 , which means that there was a difference in the average TD diastole between before and after steeping rosella, namely a reduction in $\mathrm{BP}$ of $2 \mathrm{mmHg}$.

The significance test for systolic blood pressure obtained a Sig (2-tailed) value of $0.186>0.05$, which means that $\mathrm{H} 0$ is accepted and $\mathrm{H} 1$ is rejected. This means that there is no significant difference in decreasing systolic blood pressure. Meanwhile, for diastole, the Sig. (2-tailed) of $0.446>0.05$, which means that $\mathrm{H} 0$ is accepted and $\mathrm{H} 2$ is rejected. It is also significant that for Diastole TD there is no significant difference in the provision of celery for the elderly.

This is in accordance with the results of Dian Nur Adkahana Sari's research, Giving rosella is not effective in reducing blood pressure in RT 03 dN RT 04 Candikarang Sandonoharjo Ngaklik Sleman (Roselle effectiveness against blood pressure reduction in RT 03 dN RT 04 candikarang Sandonoharjo ngaklik sleman).

\section{E. CONCLUSION}

Based on the results of research on giving rosella steeping to hypertension in the elderly in the Matraman sub-district health center, it was found that there was a difference before and after taking the action in the form of giving roselle infusion, but the difference was not significant where the significance values for both systole and diastole were 0.186 and 0.446 greater than 0.05 .

\section{REFERENCES}

1. Aris, M. (2013). Pengaruh Pemberian Seduhan. Faculty of Health Sciences UMP.

2. Dalimartha, S., Purnama, B. T., SpGK, M. S., Nora Sutarina, S., Mahendra, B., Akp, I., \& Darmawan, R. (2008). Care your self, Hipertensi. Penebar PLUS+.

3. Gilang, M. (2020). Pengaruh Pemberian Seduhan Kering Bunga Rosella terhadap Penurunan Tekanan Darah. Wellness And Healthy Magazine, 2(1), 159-164.

4. Hartiati, A., Sri, M., \& Made, D. P. (2009). Pengaruh Preparasi Bahan Baku Rosella dan Waktu Pemasakan Terhadap Aktivitas Antioksidan Sirup Bunga Rosella (Hisbiscus Sabdariffa L.). Jurnal Argotekno, 15, 20-24.

5. Jaedun, A. (2011). Metodologi Penelitian Eksperimen. Faculty of Engineering, UNY.

6. Juniarka, I. G. A., Lukitaningsih, E., \& Noegrohati, S. (2011). Analisis Aktivitas Antioksidan Dan Kandungan Antosianin Total Ekstrak Dan Liposom Kelopak Bunga Rosella. Hibiscus sabdariffa Linn L.): Majalah Obat Tradisional, (16).

7. Kowalski, R. E. (2010). Terapi Hipertensi. Mizan Publika.

8. Kusumastuti, I. R. (2014). Roselle (Hibiscus sabdariffa linn) Effects on Lowering Blood pressure as a Treatment for Hypertension. Jurnal Majority, 3(7).

9. Kuswardhani, T. (2006). Penatalaksanaan Hipertensi Pada Lanjut Usia. Jurnal Penyakit Dalam, 7(2), 135-140. 
10. Marliani, L. (2013). 100 Question \& Answers Hipertensi. Jakarta: Elex Media Komputindo.

11. Ministry of Health, (2013). Riset Kesehatan Dasar. Jakarta.

12. Pinasthika, G., Tjahjono, K., \& Nuggetsiana, A. (2011). Pengaruh Pemberian Seduhan Kelopak Kering Bunga Rosella (Hibiscus Sabdariffa) Terhadap Tekanan Darah Penderita Prehipertensi Dan Hipertensi Grade 1 Yang Diedukasi Gaya Hidup Sehat (Doctoral dissertation, Faculty of Medicine).

13. Rahajeng, E., \& Tuminah, S. (2009). Prevalensi Hipertensi dan Determinannya di Indonesia. Majalah Kedokteran Indonesia, 59(12), 580-587.

14. Saparinto, C., \& Susiana, R. (2016). Grow Your Own Medical Plant: Panduan Praktis Menanam 51 Tanaman Obat Populer Di Pekarangan. Lily Publisher.

15. Staessen, J. A., Wang, J., Bianchi, G., \& Birkenhäger, W. H. (2003). Essential Hypertension. The Lancet, 361(9369), 1629-1641.

16. Sugiharto, A. (2007). Faktor-Faktor Risiko Hipertensi Grade II pada Masyarakat (Studi Kasus di Kabupaten Karanganyar) (Doctoral dissertation, program Pascasarjana Universitas Diponegoro).

17. Suoth, M., Bidjuni, H., \& Malara, R. (2014). Hubungan Gaya Hidup dengan Kejadian Hipertensi di Puskesmas Kolongan Kecamatan Kalawat Kabupaten Minahasa Utara. Jurnal Keperawatan, 2(1).

18. Tambayong, Jan. (2000). Patofisiologi Untuk Keperawatan. Jakarta : EGC.

19. Usman, D. S., \& Winarti, S. (2016). Karakteristik dan Aktivitas Antioksidan Rosela Kering (Hibiscus sabdariffa L.)(Characteristics and Antioxidant Activity Dried Rosella (Hibiscus sabdariffa L.)). Jurnal Teknologi Pangan, 9(2).

20. Yuariski, O., \& Suherman, S. (2012). Pengeringan Bunga Rosella (Hibiscus Sabdariffa) Menggunakan Pengering Rak Udara Resirkulasi. Jurnal Teknologi Kimia dan Industri, 1(1), 1-6. 